\title{
Enkele observaties over de Netherlands Commercial Court
}

\author{
H. Koster
}

Eerlijke, onafhankelijke en onpartijdige rechtspraak is cruciaal voor een rechtvaardige samenleving. De rechter zorgt ervoor dat voor iedereen dezelfde regels gelden. Dat geeft vertrouwen in de samenleving. ${ }^{1}$ Rechtspraak maakt samenleven mogelijk. ${ }^{2}$ De afgelopen decennia heeft de samenleving een enorme ontwikkeling doorgemaakt. Zo is door invloed van globalisering de wereld 'kleiner' geworden, waardoor de samenleving en ook het bedrijfsleven in toenemende mate met andere culturen en (rechts)praktijken in aanraking komen. Een belangrijke ontwikkeling voor de rechtspraak is de explosieve groei van het internationale handelsverkeer en de daarmee samenhangende opkomst van het Engels als voertaal van het bedrijfsleven, waaronder de zakelijke dienstverlening. Onder meer als gevolg van deze ontwikkelingen is het initiatief genomen om voor de beslechting van grote internationale handelsconflicten Engelstalige rechtspraak mogelijk te maken in Nederland door de oprichting van een Netherlands Commercial Court (NCC). ${ }^{3}$ De NCC is de 'internationale handelskamer' van de rechtbank Amsterdam. Voor hoger beroep heeft het gerechtshof Amsterdam eveneens een 'internationale handelskamer', de NCCA. ${ }^{4}$ Dat is bij wet bepaald (art. 30r van het Wetboek van Burgerlijke Rechtsvordering (Rv)). De NCC en de NCCA hebben daarmee dezelfde wettelijke grondslag en dezelfde rechtsprekende taak als de overige kamers van de rechtbanken en hoven in Nederland. Met één bijzonderheid evenwel: bij de NCC en de NCCA kan in het Engels worden geprocedeerd als partijen dat wensen.

In de praktijk is recent discussie ontstaan of de NCC internationaal wel als een echte rechtbank is aan te merken, omdat partijen voor de NCC moeten kiezen. ${ }^{5}$ De gedachte daarbij was dat voor internationale erkenning van een instituut als 'rechtbank' vereist is dat het instituut van overheidswege is aangewezen voor de

1 Zie www.rechtspraak.nl/Organisatie-en-contact/Rechtspraak-in-Nederland, geraadpleegd op 25 juli 2020.

2 Zie www.rechtspraak.nl/SiteCollectionDocuments/jaarplan-van-de-Rechtspraak-2020.pdf, geraadpleegd op 25 juli 2020.

3 Kamerstukken 34761, Wet wijziging van het Wetboek van Burgerlijke Rechtsvordering en de Wet griffierechten burgerlijke zaken in verband met het mogelijk maken van Engelstalige rechtspraak bij de internationale handelskamers van de rechtbank Amsterdam en het gerechtshof Amsterdam.

4 De cassatieprocedure zal in beginsel in de Nederlandse taal moeten worden gevoerd. Prejudiciële vragen aan de Hoge Raad dienen eveneens in de Nederlandse taal te worden gesteld.

5 Zie www.mr-online.nl/van-zelst-van-doorne-twijfels-bij-europese-rechtskracht-ncc/. 
beslechting van geschillen. Nu de NCC alleen bevoegd is als partijen daarvoor kiezen, zou er geen sprake zijn van verplichte rechtsmacht, omdat de bevoegdheid alleen volgt uit de keuze van partijen en niet uit een wettelijke aanwijzing door de overheid. Vanuit de NCC is hierover begin juli 2020 een lezenswaardige publicatie verschenen, waarin mijns inziens terecht wordt verduidelijkt dat sprake is van een misvatting, omdat de keuze van partijen niet een keuze voor een afzonderlijke instantie betreft, maar alleen de keuze om geschillen in de Engelse taal te behandelen die overeenkomstig wet, verdrag of EU-verordening toch al worden behandeld door de rechtbank Amsterdam. ${ }^{6}$ Dit betekent dat alleen zaken waarvoor de rechtbank Amsterdam bevoegd is, in het Engels kunnen worden behandeld. De rechtbank Amsterdam is dus hoe dan ook al bevoegd en heeft dus rechtsmacht. De keuze van partijen is alleen een keuze om in de rechtbank Amsterdam in het Engels te procederen, meer ruimte om te kiezen is er niet. Dit betekent dus ook dat niet de NCC als zodanig bevoegdheid of rechtsmacht heeft, maar de rechtbank Amsterdam, zoals art. 30r Rv ook stelt.

Positief is ook dat inmiddels de eerste uitspraken zijn gewezen en gepubliceerd op de rechtspraakwebsite. Eveneens positief is dat er in dit coronatijdperk inmiddels sprake is van de NCC, waarbij de procedure online wordt afgehandeld met behulp van videoconferences. ${ }^{7}$ Ook noem ik dat inmiddels de eerste ondernemingsrechtelijke uitspraken door de NCC zijn gewezen. De oprichting van de NCC valt wat mij betreft vanuit het perspectief van het ondernemingsrecht toe te juichen. Ik verwacht dat de NCC meer rechtspleging van ondernemingsrechtelijke geschillen zal zien langskomen. Gedacht kan worden aan kwesties zoals onder meer geschillen over externe aansprakelijkheid van bestuurders en commissarissen of geschillen tussen aandeelhouders. ${ }^{8}$

Is er nog iets te wensen? Mijns inziens wel. Aanvullend zou het wat mij betreft ook mogelijk kunnen worden gemaakt om in het kader van een enquêteprocedure in het Engels bij de Ondernemingskamer te kunnen procederen. ${ }^{9}$ Dit zou in de toekomst nog eens moeten worden geregeld. Dat zal de reputatie van de Nederlandse rechtspraak verder versterken.

6 Zie www.rechtspraak.nl/Organisatie-en-contact/Organisatie/NCC-NL.

7 Zie www.rechtspraak.nl/English/NCC/news/Pages/The-Netherlands-Commercial-Court-andCOVID19-case-management-videoconference-hearings-and-eNCC.aspx.

8 Zie ook Kamerstukken II 2016/17, 34761, nr. 3, p. 2.

9 Zie ook mijn bijdrage 'Netherlands Commercial Court bezien vanuit het perspectief van het ondernemingsrecht', in: E. Bauw, H. Koster \& S.A. Kruisinga (red.), De kansen voor een Netherlands Commercial Court (Montaigne Centrum-reeks nr. 9), Den Haag: Boom juridisch 2018. 